\title{
Influence Cultural Organization, Assertive, Integrity, and Decision Making Towards Leadership Effectivity of the Village Chief on Gresik District
}

\author{
Erliani Budi Lestari, Muchlis R. Luddin, Maruf Akbar
}

\begin{abstract}
The goal of this research is to find the influence of the cultural organization, assertive, integrity, and decision making towards leadership effectivity of village chief from a district of Gresik. The research is held using the quantitative method using SEM (structural equation modeling). The result of this research found that (1) Cultural organization affect a positive and significant towards leadership effectivity. (2) Assertivity affect a positive and significant towards leadership effectivity;(3) Integrity affect a positive and significant towards leadership effectivity;(4) Decision making affect a positive and significant towards leadership effectivity; (5) Cultural organization affect a positive and significant towards decision making (6); Assertivity affect a positive and significant towards decision making; (7) Integrity affect a positive and significant towards decision making; (8) Cultural organization affect a positive and significant towards integrity; (9) Cultural organization affect a positive and significant towards assertive. Based on the result of the research we can conclude that Cultural organization, Assertive, Integrity, and Decision making affect a positive and significant towards leadership effectivity of village chief from a district of Gresik.
\end{abstract}

Index Terms: Cultural Organization, assertive, Integrity, Decision making, Leader Effectivity.

\section{INTRODUCTION}

Based on the legislation of Indonesia which set about the leadership of village chief, known that leadership effectivity of village chief needed to organize the government affairs in the village state. Unfortunately, the implementation that happened, in reality, showed that the figure of the village chief in the environment still less active to revive the society and institutional organization in the village. The other hand, the village chief also less than optimal in delivering information towards society like realizing socialization and meeting to discuss the problem in the environment that needs citizen opinion (Amat, 2015:1-15). The village chief also still cannot create the work atmosphere that can improve the work satisfying in community

\section{Revised Manuscript Received on September 22, 2019}

Erliani Budi Lestari, Student of Postgraduated Universitas Negeri Jakarta (UNJ) Indonesia, erlynarema@gmail.com

Muchlis R. Luddin, Lecturer of Postgraduate UNJ Indonesia, wr1@unj.ac.id

Maruf Akbar, Lecturer of Postgraduated UNJ, maruf.akbar@unj.ac.id
service(Triwidodo,2014:1-15). It shows that the role of the village chief as the leader in the village is less than optimal. Leadership a village chief needed to be able to protect the community also with the village equipment that helps management his reign.

Rests on the task to do by the village chief hence a person who given the messages as the village chief is required to have adequate competence to be able to realize leadership effectively, so that can assume and carry out duties that carried by the legislation. It because of the leadership effectivity will impact in performance organization (Popa, 2012:123-126).

The role of the village chief as a leader in the scope of village Demanding the effectiveness of high so as to restore the region through empowerment village official. It is felt like a hard thing when there is an overlapping between the task and the obligation who appointed towards the village chief by the local government through the various policies and regional regulation in practically the village chief real work, where the village chief is still considered as the ruler of the district by the citizen so often sued for involvement in every society event also asked to be able to fix the problem directly, without passing through the official and regional official under power the village chief.

Deporting from that phenomenon, then the leadership of the village chief cannot run maximally, or in the other word less than effective and potency as caused as performance regions that cannot run as good as possible. The village chief sued for running the duty whose messages in regional legislative regulations but yet despite from citizen opinion who demanding intricacy and complexity the village chief work, which cause the decline in the effectiveness of the village chief leadership. It needs a deep assessment to know the factor that can increase the work of the village chief, so that when on one side the village chief still involved in the complexity of work but the other side can happen is a positive encouragement to increase the effectiveness of the village chief leadership.

The study literature shows that the effectiveness of leadership influenced by many factors, like cultural organization (Ali \& Patnaik, 2014:1-20),

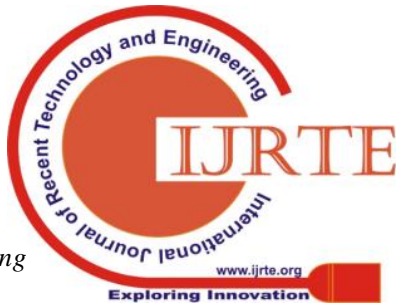


Decision making (Snowden \& Boone,2007:1-10), Assertive (Ames,2009:111-133), and integrity (Moorman \& Grover, 2009:1-13). See in some study literature and empirical before can be explained that there are factors affecting leadership and the inter correlation between the decision making with assertive, integrity, and cultural organization. Meanwhile, if reviewed conceptually, leadership theory has a relation with the implementation of the value and culture in the organization also the impact on work attitude, commitment, and decision making. That is why in this research, to observe the influence of the cultural organization, and leadership that is effective against ability in decision making and inter correlation with assertive, integrity, upon the whole the village chief on the Gresik district.

Based on exposure to the phenomenon in the beginning, So the formulation of a problem in this research are:

- Do cultural organization influential on the effectiveness of the village chief leadership on the Gresik district?

- Do certify influential on the effectiveness of the village chief leadership on the Gresik district?

- Is integrity influential on the effectiveness of the village chief leadership on the Gresik district?

- Is decision making influential on the effectiveness of the village chief leadership on the Gresik district?

- Do cultural organization influential on the decision- making of the village chief on the Gresik district?

- Do certify influential on the decision making of the village chief on the Gresik district?

- Do integrity influential on the decision making of the village chief on the Gresik district?

- Do cultural organization influential on the integrity of the village chief on the Gresik district?

- Do cultural organization influential on the assertive of the village chief on the Gresik district?

\section{LITERATURE REVIEW}

\section{A. Leadership}

In etymological, the term leadership derives from the verb "lead" which mean the people who guiding or lead. In comprehensive, the concept of leadership in the organization is 'as the individual in the group given must the task of directing and coordinating task-relevant group activities' it means leadership must direct and coordinate performances to achieve the aim to influence organization activity (Datta, 2006:44). Leadership has two basic concepts, that "leadership is more about what others do not see than what they do see" (kepemimpinan berkaitan dengan berbagai hal yang dilakukan tanpa terlihat daripada hal-hal yang dilakukan dengan terlihat oleh orang lain), and "leadership is the integration of character, knowledge, skill, and desire" (kepemimpinan adalah integrasi antara karakter, pengetahuan, kemampuan, dan keinginan) (Adeniyi, 2007:12). Leadership concept basically having the incarnation of urgency, and the importance of leader as an individual possessing, behavior, power, or influence, situational, integrative on the dimension of life organization as a manifestation of on power, to exert the potential in a harmonic way and guarantee his followers in achieving the next goal.

\section{B. The Effectiveness of Leadership}

Peter Drucker (2008:67) emphasizing the term of effectiveness at three main points that underlie any kind of process which can be called effective, at the knowledge of the things to be done, knowing the procedure, and knowledge, and ability to finish. Further analysis effectivity defined as "the power or ability to bring about the desired results", that the effectiveness of is the power, or ability to achieving an expected result. An organization is said to have the work effectiveness when the whole process and the use of owned resources can be achieving the result that set as an organization target. (Adeniyi, 2007:13). Next, the explanation about the effectiveness of leadership is the size of subjectivity resulting from the highest leader based on the human relationship between the worker or subordinate or said as a contributions leader at the group process that felt by the follower or the inspectors from the outside (Datta, 2015:62-75). Further to, the effectiveness of leadership also taken of the role, duty, function, nor responsibility according to skills, knowledge, talent, also characteristic of another person that leads to superior performance (Mcshane \& Glinow, 2010:45).

\section{Decision Making}

Decision making refers to the process of arousing and choosing from a set of an alternative way to solve the problem (Colquitt, 2011:101). An alternative that referred to this thing could include factual premise and value, such as a preferred human activity from one or more alternative with the intention at a number of the coveted state. According to Rational Theory, decision making is something that is done intentionally with based on the rational thought from several choices, that was decided to chosen and serve as a platform from behavior or attitude, both in level individual or organizational. So it will be known the theory sintesa decision making that the decision making is a course of action that involved many parties from the top level (top), to the lower levels (bottom) to review some of the issues that must be resolved to produce the achievement of the aims.

\section{Cultural Organization}

Tobari (2015:46) citing the opinions of several experts, among other: Robbins, the handling of cultural organization as "a system of shared meaning held by members that distinguishes the organization from other organization", it

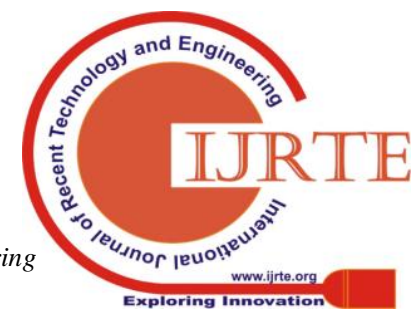


means, the cultural organization is a shared value system that admitted and adopted by the organization member, which differentiates an organization from other organizations.

According to John Keyton (2011:1), the cultural organization is "the set of artifacts, values, and assumptions that emerge from the interactions of organizational members", it means the cultural organization is a series of an artifact, value, and assumption that come from interaction around the organization member.

\section{E. Assertiv}

Sue Hadfield and Gill Hasson (2010) explain that “Assertiveness isn't about being loud and threatening or always getting your own way. That is aggression. Keeping quiet and going along with what another want isn't always the best way to behave. That is being passive. Manipulating others and avoiding responsibility for getting your needs met is not a fair way to behave either. That is being passive- aggressive. Assertiveness is an entirely different approach to meeting your needs. It is about letting others know what you do and do not want in a confident and direct way. Both passive and aggressive people relate to others as though only one person counts: themselves. In contrast, assertive people are concerned with a fair deal for everyone", the point of the explanation is that assertive not including aggressive or passive behavior. The aggressive behavior had the characteristic of doing everything in a hard way, and always aims to meet its own sake, otherwise, the passive behavior tends to have the characteristic reticence and following the wills of the other.

\section{F. Integrity}

Integrity leadership theory explains that a leader has to formulate an organization behavior he is leading through his words into real action, or there is a consistency between his words and actions. Therefore, integrity leadership must have the commitment to do it, the commitment and consistency to be the criteria need to be considered in realizing it. To realize it needs hard work through the correlation cognitive aspects, effective, and psychomotor that reflects in holistic as a leader (McShane \& Glinow, 2010:45).

\section{G. Conceptual Framework}

Based on the formulation of the problem, and the literature review that has been described in the previous chapter conceptual framework refers to theories and relevant previous research. As an illustration in a comprehensive manner towards the connection between a variable that used on the research model, below served research conceptual framework chart. Where that research framework can be illustrated in (figure 1) in the following.

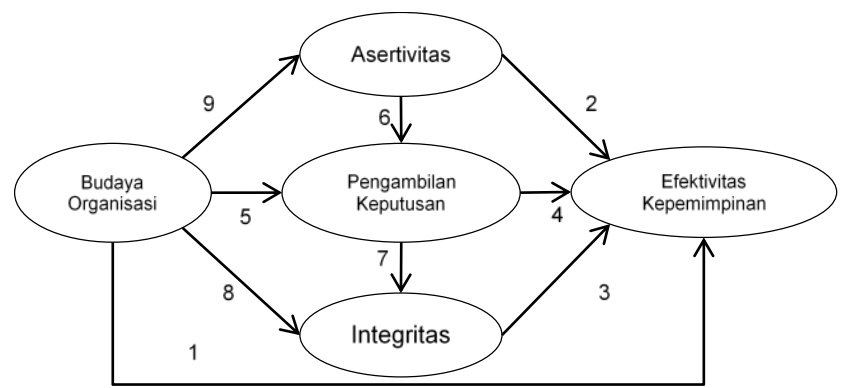

Fig. 1. Conceptual Framework

- Based on the discussion description Theories and conceptual framework above then it can be submitted hypothesis in the following below:

- Cultural organization affect the effectiveness of leadership the village chief on Gresik district

- Assertive affect the effectiveness of leadership the village chief on Gresik district

- Integrity affect the effectiveness of leadership the village chief on Gresik district

- Decisionmaking affect the effectiveness of leadership the village chief on Gresik district

- Cultural organization affect the decision making of the village chief on Gresik district

- Assertive affect decision making of the village chief on Gresik district

- Integrity affect decision making of the village chief on Gresik district

- Cultural organization affect the integrity of the village chief on Gresik district

- Cultural organization affect the assertive of the village chief on Gresik district

\section{METHODOLOGY}

This research using a quantitative flow with survey method, the method that collecting the data based on a question that deliver towards the respondent who designed to get the information from the respondent. Where the research is held by collecting data through the statement that must be answered by the village chief and village officials on Gresik district who become a sample for the research. Next, the procedure for collecting the data that be used is structured data collection with the questioner. The population of the research is taken based on the primary data sources that acquired from the village chief and village officials of Gresik district which consist of 366 villages and political district. The village chief election in Gresik district accumulated by the amount of 339 peoples.

\section{RESULT AND FINDINGS}

The model in the analysis of this research is using SEM (Structural Equation Modelling). In this research, processing and data analysis performed using AMOS version 2.0. As for the analysis carried out as follows:

\section{A. A Test of Normality to Scatter and Linearity}

The distribution normality

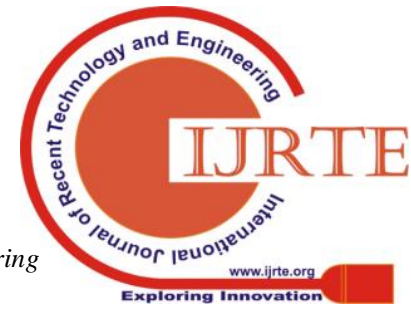


test performed with kurtosis value from the usual data used is presented in descriptive statistics. Statistic value to test the normality it called $\mathrm{Z}$ - value. If the value of $\mathrm{Z}$ is bigger than the critical value that can be expected the data distribution is not normal. Critical value can be determined by the significance level $0,01[1 \%]$ that is equal to $\pm 2,58$, the test result shows that critical value multivariate is outside the $\pm 2,58$ it means the normality assumption not fulfilled.

This phenomenon is not a serious problem like it said by Bentler \& Chou (1987) that if the estimation technique in the SEM model using a maximum likelihood estimation (MLE) even though the data distribution is not normal but still can produce the good estimate, so that data worthy to use in the next estimation.

\section{B. Evaluation of Outliers}

The multivariate outlier is tested by distance criteria Mahalanobis at level $\mathrm{p}<0,001$. The distance is tested with Chi-square $[\chi 2]$ in the amount of free variable $(\mathrm{df}=724)$. Note: if Mahalanobis > from [ $\chi 2]$ value is a multivariate outlier. On this research, there is an outlier when the value of Mahalanobis distance $>847,312$. Based on the tested that have done, is known MD maximum value is 289,080 smaller than 847,312 . Therefore, it was decided in research there are no outlier violations.

\section{Multi Collinearity and Singularity}

Based on the test results using the AMOS program 22.0 obtained result Determinant of Sample Covariance Matrix is $>0$ amounting to 73,946 indicate does not happen Multi collinearity and Singularity in this data so the assumption can be fulfilled

\section{Validity Test Result and Reliability}

Based on confirmatory factor analysis result seen that factor loadings each question indicators that created every variable most of the $>0,5$ so the instrumentation indicators every construct can be said the validity is good enough and can be accepted. While the reliability test results in internal consistency for every variable above shows good thing where the Cronbach's Alpha coefficient obtained entirely fulfilled rules of thumb which are hinted by $\geq 0,7$ (Hair et.al.,1998).

\section{E. Model Testing}

In the SEM, measurement model and structural model parameters are estimated together. This way experiences a little trouble in fulfilling demands fit model. The biggest possible caused by the interaction between the measurement model and the structural model that estimated together (One Step Approach to SEM). One step approach to SEM used if the model believed that based on strong theory also validity and reliability data are very good. This estimated result and fit model one step approach to SEM using application program AMOS 22.0 that seen in the picture and the table Goodness of fit below.

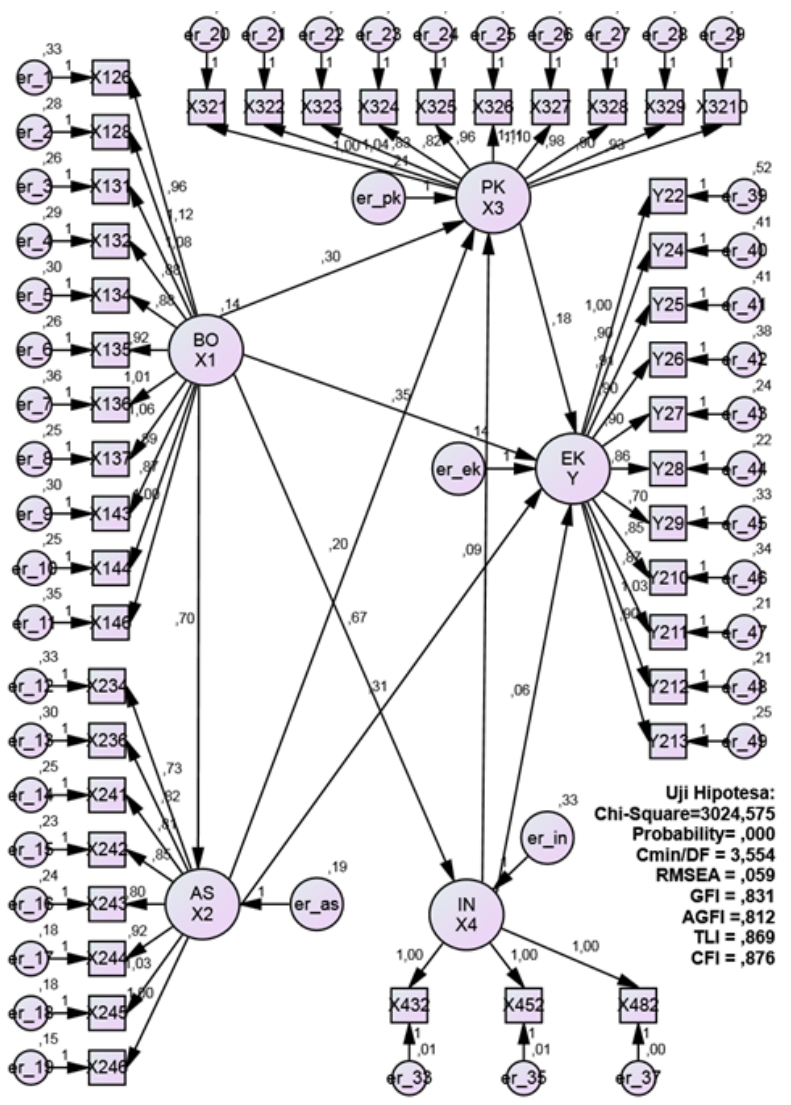

Fig. 2. One Step Approach model

Table 1. Evaluation criteria Goodness of Fit Indices

\begin{tabular}{|l|r|c|c|}
\hline \multicolumn{1}{|c|}{ Criteria } & \multicolumn{1}{c|}{ Result } & Critical Value & Model Evaluation \\
\hline Cmin/DF & $3.024,575$ & Expected Small & Marginal \\
\hline Probability & 0,000 & $\geq 0,05$ & Not Fit \\
\hline RMSEA & 0,059 & $\leq 0,08$ & Fit \\
\hline GFI & 0,831 & $\geq 0,90$ & Marginal \\
\hline AGFI & 0,812 & $\geq 0,90$ & Marginal \\
\hline TLI & 3,554 & $\leq 2,00$ & Not Fit \\
\hline CFI & 0,869 & $\geq 0,90$ & Marginal \\
\hline
\end{tabular}

Source: Primary data processed 2018

From the evaluation result to one step approach model it turns out from all the criteria goodness of fit which is used, one of them has shown good model evaluation result, it means the model has fit with the data. It means a conceptual model is developed and based on the theory that had fully supported by the fact. Therefore, this model is the best model to explain the connection between the variables in the model in this research.

Table 2: Causality Test Result 


\begin{tabular}{|l|l|l|r|r|r|r|}
\hline \multicolumn{1}{|c|}{ Factor } & $\Rightarrow$ & \multicolumn{1}{|c|}{ Factor } & $\begin{array}{c}\text { U std } \\
\text { Estimate }\end{array}$ & $\begin{array}{c}\text { Std } \\
\text { Estimate }\end{array}$ & $\begin{array}{c}\text { Causal } \\
\text { Probabilty }\end{array}$ & \multicolumn{1}{|c|}{ Notes } \\
\hline Cultural Organization & $\Rightarrow$ & Assertive & 0,704 & 0,513 & 0,000 & Significant \\
\hline Cultural Organization & $\Rightarrow$ & Integrity & 0,668 & 0,402 & 0,000 & Significant \\
\hline Cultural Organization & $\Rightarrow>$ & Decision Making & 0,295 & 0,221 & 0,000 & Significant \\
\hline Integrity & $\Rightarrow>$ & Decision Making & 0,088 & 0,109 & 0,000 & Significant \\
\hline Assertive & $\Rightarrow>$ & Decision Making & 0,196 & 0,201 & 0,000 & Significant \\
\hline Cultural Organization & $\Rightarrow>$ & Leadership Effectivity & 0,351 & 0,266 & 0,000 & Significant \\
\hline Assertive & $\Rightarrow>$ & Leadership Effectivity & 0,313 & 0,326 & 0,000 & Significant \\
\hline Decision Making & $\Rightarrow>$ & Leadership Effectivity & 0,183 & 0,185 & 0,000 & Significant \\
\hline Integrity & $\Rightarrow$ & Leadership Effectivity & 0,057 & 0,072 & 0,049 & Significant \\
\hline \multicolumn{7}{|c|}{ Critical Value $(<0,05)$} \\
\hline
\end{tabular}

Source: Primary data processed 2018

\section{F. Hypothesis Testing and Casual Relationship}

See from the determinant of the number of sample covariance matrix: $73,946>0$ indicated not occur multicollinearity or singularity on this data so the assumption can be reached. Therefore, the amount of regression coefficient each factor can be trusted as seen in table 2 .

Seen from the probability direction of relationship level, the hypothesis states that:

- Cultural Organization variable has had a positive impact on Assertive variable, acceptable (causal probability $0,000 \leq 0,05$, significant, positive).

- Variable Cultural Organization variable has had a positive impact to Integrity variable, acceptable (causal probability $0,000 \leq 0,05$, significant, positive).

- Variable Cultural Organization variable has had a positive impact to Decision Making variable, acceptable (causal probability $0,000 \leq 0,05$, significant, positive).

- Variable Integrity variable has had a positive impact to Decision Making variable, acceptable (causal probability $0,008 \leq 0,05$, significant, positive).

- Variable Assertive variable has had a positive impact to Decision Making variable, acceptable (causal probability $0,000 \leq 0,05$, significant, positive)

- Variable Cultural Organization variable has had a positive impact to Leadership Effectivity variable, acceptable (causal probability $0,000 \leq 0,05$, significant, positive).

- Variable Assertive variable has had a positive impact on Leadership Effectivity variable, acceptable (causal probability $0,000 \leq 0,05$, significant, positive).

- Variable Decision Making variable have had a positive impact on Leadership Effectivity variable, acceptable (causal probability $0,000 \leq 0$, significant, positive).

- Variable Integrity variable has had a positive impact on Leadership Effectivity variable, acceptable (causal probability $0,049 \leq 0,05$, significant, positive).

\section{G. Results}

The result from measurement model, as described before, shown that every variable indicator is valid that reflected research variable, remember the value loading factor most of the $\geq 0.5$, So the instrument items each construct validity can say good enough, and acceptable. The results of those analyses also showed the strongest indication that reflects each variable research. Based on the hypothesis test the results showed in the following below:

- Cultural organization Impact on the effectiveness of village chief leadership on Gresik district. These studytest results have shown that cultural organization impacts a positive and significant to leadership effectiveness. This result is indicated by probability values obtained by 0,000 where the value is smaller than the cut off value which stated term 0,05 . These result showed that with the cultural positive cultural organization, can be able to support the leadership which is effective in accordance with needs the parties involved below. For that can be taken a connection to the hypothesis that stated cultural organization has an impact on the effectiveness of the leadership of the village chief on Gresik district can be trusted.

- Assertive effect on the effectiveness of village chief leadership on Gresik district. These study tests result shown that assertive have had a positive and significant impact on leadership effectiveness. These results have shown by the probability values obtained by 0,000 where the value is smaller than the cut off value which stated term 0,05. These result showed that with the good assertive, will be able to support the leadership which is effective in accordance with needs the parties involved below. Therefore, can be taken a connection to the hypothesis that stated cultural organization has an impact on the effectiveness of the leadership of the village chief on Gresik district can be trusted.

- Integrity effects on the effectiveness of village chief leadership on Gresik district. These study tests result shown that integrity has had a positive impact and significant on leadership effectiveness. These results have shown by the probability values obtained by 0,049 where the value is smaller than the cut off value which stated term 0,05. These result showed that with good Integrity, will be able to support the leadership which is effective in accordance with needs the parties involved below. Therefore, can be taken connection to the hypothesis that stated integrity has an impact on the effectiveness of the leadership of the village chief on Gresik district can be trusted.

- Decision making influences the effectiveness of village chief leadership on Gresik district. These study 
tests result shown that decision making has had a positive and significant impact on leadership effectiveness. These results have shown by the probability values obtained by 0,000 where the value is smaller than the cut off value which stated term 0,05 . These result showed that with good Integrity, will be able to support the leadership which is effective in accordance with needs the parties involved below. Therefore, can be taken a connection to the hypothesis that stated Decision making has an impact on the effectiveness of the leadership of the village chief on Gresik district can be trusted.

- Cultural organization influence on decision making the village chief on Gresik district These study tests result shown that cultural organization has had a positive and significant impact on decision making. These results have shown by the probability values obtained by 0,000 where the value is smaller than the cut off value which stated term 0,05 . These result showed that with a good cultural organization, will also be able to support good decision making. Therefore, can be taken a connection to the hypothesis that stated cultural organization has an impact on the decision making of the leadership of the village chief on Gresik district can be trusted.

- Assertive influence on decision making the village chief on Gresik district These study tests results shown that assertive has had a positive and significant impact on decision making. These results have shown by the probability values obtained by 0,000 where the value is smaller than the cut off value which stated 0,05 . These result showed that with good assertive, will also be able to support good decision making. Therefore, can be taken a connection to the hypothesis that stated assertive has an impact on the decision making of the leadership of the village chief on Gresik district can be trusted.

- Integrity influences on decision making the village chief on Gresik district. These study tests result shown that integrity has had a positive and significant impact on decision making. These results have shown by the probability values obtained by 0,008 where the value is smaller than the cut off value which stated 0,05 . These result showed that with good integrity, will also be able to support good decision making. Therefore, can be taken a connection to the hypothesis that stated integrity has an impact on the decision making of the leadership of the village chief on Gresik district can be trusted.

- Cultural organization influences on Integrity the village chief on Gresik district. These study tests result shown that cultural organization has had a positive and significant impact on integrity. These results have shown by the probability values obtained by 0,000 where the value is smaller than the cut off value which stated 0,05 . These result showed that with a good cultural organization, will be able to encourage higher the integrity of officials. Therefore, can be taken a connection to the hypothesis that stated cultural organization has an impact on the integrity of the village chief on Gresik district can be trusted.

- Cultural organization influences on assertive the village chief on Gresik district. These study tests result shown that cultural organization has had a positive and significant impact on assertive. These results have shown by the probability values obtained by 0,000 where the value is smaller than the cut off value which stated 0,05 . These result showed that with a good cultural organization, will be able to encourage the higher assertive from officials. Therefore, can be taken a connection to the hypothesis that stated cultural organization has an impact on the assertive of the village chief on Gresik district can be trusted.

\section{CONCLUSION}

\section{A. Conclusion}

- Based on the results, we can conclude the important things in the following below:

- This test result showed that cultural organization have had a positive impact and significantly correlates with the effectiveness of leadership.

- This test result showed that assertive influential positive and significantly to the effectiveness of leadership.

- This test result showed that integrity influential a positive and significant to the leadership effectiveness.

- This test result showed that decision making have had a positive and significant impact the leadership effectiveness.

- This test result showed that cultural organization influential a positive and significant to decision making.

- This test result showed that Assertively influential a positive and significant to decision making.

- This test result showed that integrity influential a positive and significant on decision making.

- This test result showed that cultural organization influential a positive and significant on the integrity.

This test result showed that cultural organization influential a positive and significant to assertive.

\section{B. Suggestion}

Based on the conclusion that has described before, so the suggestion put forwards:

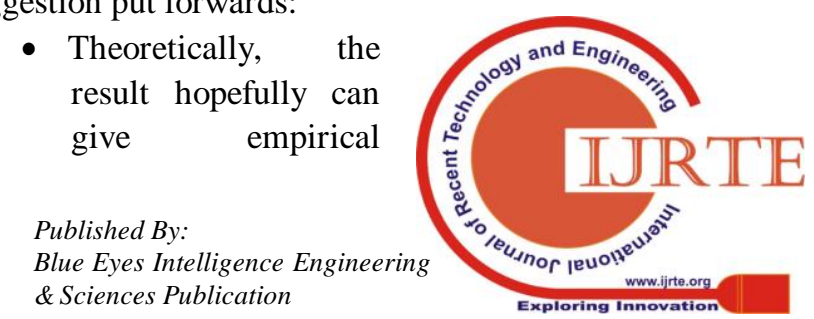


evidence to defining the causal relationship between several variables which comprehensively concerned, so useful in the theoretical, where(a) For enriching the analysis and develop a model which showed the role of the effectiveness of the leadership of the region as an intermediary in the ability to decision making, and the inter correlation with assertive, integrity, and cultural organization, and hopefully can be discourse for the next research correlate with leadership effectiveness of the leadership of the region also with measurement elements; and(b) This research can be used as a reference for the next researchers, Whose aim is to bring the theory leadership that effective in other areas (region) to expand khazanah theoretical, and raised values the culture of the nation a pluralistic in the future.

- Practically, the result hopefully can give feedback to all the village chief on Gresik district in making decisions that will provide the effectiveness maximally in the role of leadership according to assertive, integrity, and institutional culture, or organization in his region, and also can be a feedback to all the village chief on Gresik district to known the condition of leadership effectiveness in his region who are considered effective or not.

\section{REFERENCES}

[1] Adeniyi, M. A. (2007). Effective Leadership Management: An Integration of Styles, sKills \& Character for Today's CEOs. Bloomington: Author House.

[2] Ali, Amjad \& Bhaswati Patnaik. 2014. Influence of Organizational Climate and Organizational Culture on Managerial Effectiveness: An Inquisitive Study, The Carrington Rand Journal of Social Sciences, June 2014, Vol. 1, No. 2, p. 001-020.

[3] Amat, A. W. (2015). Peranan Kepala Desa Dalam Pemberdayaan Masyarakat: (Penelitian di Desa Kepala Gurung Kecamatan Mentebah Kabupaten Kapuas Hulu). Jurnal S-1 Ilmu Pemerintahan, 1-15.

[4] Ames, Daniel R. 2009. Pushing Up to a Point: Assertiveness and Effectiveness in Leadership and Interpersonal Dynamics, Research in Organizational Behavior 29 (2009), p.111-133.

[5] Colquitt, J. A., LePine, J. A., \& Wesson, M. J. (2011). Organizational Behavior: Improving Performance and Commitment in the Workplace. Second Edition. New York: McGraw-Hill.

[6] Datta, A.K. (2006). Material Management: Procedures, Text and Cases, Second Edition. New Delhi: Prentice-Hall of India Private Limited.

[7] Hadfield, S, \& Hasson, G, 2010, How to Be Assertive in Any Situation, Pearson Life.

[8] Keyton, J, 2011, Communication \& Organizational Culture: A Key to Understanding Work Experiences, Edition 2, California: Sage Publications, Inc., 2011, h. 1.

[9] McShane, S. L., \& Glinow, M. A. (2010). Organizational Behavior, 2 Ed. New York: McGraw-Hill.

[10] Moorman, Robert H. \& Steven Grover. 2009. Why Does Leader Integrity Matter to Followers? An Uncertainty Management-Based Explanation, International Journal of Leadership Studies, Vol. 5 Issue. 2, 2009, p.1-13.

[11] Popa, Brindusa Maria. 2012. The Relationship Between Leadership Effectiveness and Organizational Performance, Journal of Defense Resources Management, Vol. 3, Issue 1 (4) 2012, p. 123-126.

[12] Snowden, David J. \& Mary E. Boone. 2007. A Leader's Framework for Decision Making, Harvard Business Review, November 2007, p. 1-10.

[13] Tobari, 2015, Membangun Budaya Organisasi Pada Instansi Pemerintahan, Yogyakarta: Deepublish, h. 46

[14] Triwidodo, E. (2014). Kepemimpinan Kepala Desa Dalam Pembangunan Masyarakat di Desa Sebunga Kecamatan Sajingan Besar Kabupaten Sambas. Jurnal S-1 Ilmu Pengetahuan, 1-15.

\section{AUTHORS PROFILE}

My name is Erliani Budi Lestari, I am Student of Postgraduated Universitas Negeri Jakarta (UNJ) Indonesia my area of ineptest is management and leadership.

My name is Muchlis R. Luddin, I am working as Lecturer of Postgraduate UNJ Indonesia,

My name is Maruf Akbar, I am working as Lecturer of Postgraduated UNJ, Indonesia my area of ineptest is management and leadership. 